\title{
Entrepreneurship, Skill Acquisition and Economic Growth
}

\author{
Sunday Okubor Ijieh \\ http://dx.doi./org/10.4314/ujah.v21i3.6
}

\begin{abstract}
Scientifically, the relationship between knowledge and growth in economic growth has been enhanced by technical breakthroughs and developments over the years, so that economic growth is no longer focused solely on the exploitation of raw materials, energy sources and physical goods, but on the intangible development of values in the form of essential skills, services, innovative technologies and inventions. Considering the high level of youth unemployment and the high incidence of poverty in Nigeria, this requires a re-adjustment of the traditional methods of human capital growth. The main goal of this paper is to shed light on recent developments in our understanding of the forces that border on information formation, distribution and innovation through the growth phase of the entrepreneur. This paper explored the tertiary institutions' entrepreneurship development programme and the capacity of graduates and future graduates to build jobs. Therefore, at Issele-Uku Delta State NYSC orientation camp, forty youth corps members were surveyed to evaluate their entrepreneurial dispositions. Similarly, surveys were also performed at four Delta State Tertiary Institutions. The sample of institutions consisted of 20 students from the selected schools each. One hundred polled 20 respondents. It was found that thirty-two percent of those who admitted to have taken entrepreneurship education, showed interest in setting up personal businesses using X2 analytical technique, while twenty-two percent preferred to work in private agencies, and the remaining forty-six percent preferred to work in either of the government weapons. In the design of regulations affecting the development of knowledge for the efficient diffusion of knowledge into socially useful needs, the policy implications of this study are significant.
\end{abstract}


Keywords: Entrepreneurs, Knowledge, Innovation, Growth

\section{Introduction}

Unemployment and poverty tend to be the most important among the many socio-economic challenges faced by the Nigerian nation today. ILO figures (2014) indicate that the unemployment rate fluctuated between $7.3 \%$ in 1986 and $20.51 \%$ in 2014, fostering a high level of poverty. Several young people in Nigeria are unemployed and thus pose a security risk to the more fortunate and innocent citizens.Different government regimes have made many attempts to reduce unemployment by generating jobs in the public and private sectors through the diverse development agenda, but the problems seem to be unabated. It is widely believed, according to Schoof (2010), that people who have a flair for entrepreneurship and skill acquisitions are more likely to start companies, build jobs, and make more positive contributions to economic growth and the reduction of poverty.Several academics and politicians alike corroborate this point. The word entrepreneur, for example, has been explained in various ways by different authors. One of the leading economists, Jean Baptist Say, perceives the term to mean someone who has the ability to allocate capital to increase economic competitiveness and growth.

The classicists, however, see the entrepreneur as a scarce resource coordinator, so that the allocation of resources becomes more successful and thus increases productivity with growth. In addition, Schumpeter (1943) sees an entrepreneur as one who is imaginative and inventive, who overturns known modes of production and generates economic imbalances that lead to new opportunities required to improve productivity. Is there a need for a thorough understanding of the interface between entrepreneurial awareness, skill development and economic growth in an innovation-driven world?The innovation process is a feature of access to existing information and is therefore deemed to be one of the critical issues in 
the understanding of development. Innovation is one vehicle that diffuses and upgrades existing information, thereby acting as a medium for the realization of spillovers of knowledge. Innovation often involves an improvement in the inventory of valuable information through the learning of skills.In most North American countries, entrepreneurship, skill development and creativity have been identified as major determinants of economic growth (Zoltan and Audretsch, 2009). Increased entrepreneurial activities in the area have resulted in sustained economic growth and regulated unemployment over the past 20 years, he also explained. Similarly, Audretsch and Keilbach (2005) show that the ability of entrepreneurship to boost growth rates and minimize unemployment has been realized by researchers and policy makers in Europe and Asia. Zoltan and Audretsch have shown emphatically that regions or sectors with higher levels of entrepreneurship have higher levels of innovation and economic development.This indicates that including entrepreneurial education in learning institutions ensures that as they gain skills and vocational experience while in school, school graduates are likely to start new businesses, as common wisdom seems to support the view that entrepreneurship plays an important role in the knowledge-based economy. Theoretical and empirical evidence seem to support the view that localized processes are knowledge creation, creativity and entrepreneurship processes.Thus, the main objective of this paper is to shed light on the development of innovations, new information and its dissemination in the growth process through creativity and entrepreneurship.

\section{Conceptual Issues}

An entrepreneur is one who, by combining his imagination and experience with a strategic aim and vision, is able to turn opportunity into economic value. Entrepreneurs are the means by which business decisions involving risks and uncertainties can communicate 
innovative and creative ideas (Braunerhjelm, 2010). An entrepreneur can be described as a person who, by the successful use of his experience, passion, dreams and desires, intends to add value to the economy by creating a new business venture.An entrepreneur is an entity who assesses the current environmental situation and directs the making of certain changes or alternatives in the economic or manufacturing structures as he considers necessary to achieve the desired results (Acs \& Armington, 2006).

Entrepreneurship is nothing but practices performed by the entrepreneur that include processes such as creativity, risk-related and unpredictable decision-making. Shane and Venkataraman (2000) defined entrepreneurship as the "how, by whom and with what goods and services are discovered, assessed and exploited". This means that, under uncertainties, the entrepreneur is one who perceives and generates new creative possibilities.

\section{Theoretical Issues}

An entrepreneur, in the words of Emordi (2013), helps to shift the economy to an optimal location on the production possibility curve of output. Entrepreneurs from the Schumpeterian perspective are also considered to be innovators. To date, entrepreneurial theories and models have largely failed to discuss the position of independent innovators (entrepreneurs) and their contributions to economic development. The accumulation (in the form of knowledge and capital) of output factors alone cannot explain economic growth. The creative expertise of the entrepreneur is needed to turn these factor inputs into successful projects.

Entrepreneurship's knowledge Spillover Theory shows that businesses live exogenously and then endogenously search for and apply knowledge inputs to produce creative output. It is the information in the hands of economic agents that is exogenous, and the spillover of knowledge from its generating organization entails 
endogenously forming a new business in an attempt to appropriate the returns from that knowledge. The spillover of knowledge creates opportunities for the start up of new firms through exploiting knowledge created by R\&D units in corporations and tertiary institutions. Analyzing differences in start-up rates across various industries representing different underlying knowledge contexts provided empirical evidence supporting the knowledge spillover theory of entrepreneurship. In particular, those industries with higher investment in new knowledge also showed higher start-up rates, whereas those industries with lower investment in new knowledge showed lower start-up rates, which were interpreted as a conduit that transmits spillovers of knowledge (Caves, 2008).Significant evidence has therefore been given to indicate that entrepreneurship is an endogenous response to opportunities created by incumbent firms but not exploited by them. This involved an organizational dimension involving the transmission process of spillovers of information. Evidence concerning the spatial dimension of information spillovers was presented by Audretsch and Stephan (1996).The results of their research indicate that spillovers of information are found within the vicinity of the source of knowledge. Studies indicate that there are no definite mechanisms that explicitly transmit the spillover of information; rather, spillover transmissions are implicitly believed to occur naturally within the geographical source of knowledge (Caves, 2008).

As a significant source of entrepreneurial potential, the knowledge spillover hypothesis of entrepreneurship describes new concepts and knowledge. The knowledge spillover theory of entrepreneurship posits, to be exact, that it is new knowledge and ideas generated in one sense and actively pursued by the source that creates certain ideas that serve as a source of knowledge that generates entrepreneurial opportunities.The organization that produces possibilities is not always the same organization that utilizes 
the possibilities it provides. By obtaining a franchise, license or royalty, which serves as a knowledge spill-over mechanism, prospective entrepreneurs may appropriate or manipulate knowledge spill-overs in their development push. In creating entrepreneurship opportunities, innovative ideas and expertise play an important role.The endogenous growth model of Romer (1986) shows that it is believed that new technical information will automatically spill over. Third-party companies and economic agents directly access investment in new technical information, resulting in the automatic spillover of knowledge. The assumption that knowledgespills over automatically is consistent with the essential perspective of Arrow (1962), who assumes that knowledge varies from conventional development factors (physical resources and labour), in that, it is not an exclusive preservation or exhaustive preservation (Audretsch \& Keibach, 2005).

\section{Empirical Issues}

The role of entrepreneurship in economic development, business expansion, innovation and unemployment reduction has been substantially evaluated by several research studies. Innovation and entrepreneurship are required, in the opinion of Adam Smith (1776), to turn new knowledge and ideas into productive ventures. The need to move from a regulated economy to an entrepreneurial economy has become the subject of policy discussion, as more and more research studies show that a good entrepreneurial climate contributes to sustainable economic growth.The role of entrepreneurship in economic development, market expansion, innovation and unemployment reduction has been scientifically evaluated by academic studies in developed countries. This study has consistently shown that regions or sectors with higher levels of entrepreneurship are experiencing higher levels of innovation and economic development. As a result, most European countries are recognizing 
the potential of entrepreneurship by adopting policy initiatives to boost their entrepreneurship skills to increase growth rates and minimize unemployment levels.

Some research, such as Siyanbola; Afolabi, Jesuleye, Egbetokun; Dada; Aderemi, et-al (2009), have confirmed the effectiveness of the use of education in entrepreneurship to stimulate entrepreneurial choice. Their research concluded that entrepreneurship education has a positive effect on students' career choices.The outcome of these studies is that, if entrepreneurship education is made compulsory in all our higher learning institutions, youth unemployment will soon be a thing of the past. Charney and Libecap (2003) argued that it is common wisdom that certain individuals are born entrepreneurs and can succeed with or without education, while for those who lack the "entrepreneurial spirit," no amount of education will provide business success.

Obembe and Adeleye (2015) show that in Akwa-Ibom and Cross Rivers states in Nigeria's South-South geo-political region, Ekpoh and Edet (2011) examined the impact of entrepreneurship education and career intent of tertiary education students. The research used a standardized questionnaire completed by 500 students; frequency counts, percentage and population T-test were used to evaluate the results. The outcome showed that most students (29.6 percent) chose to go to paid jobs, 26.8 percent suggested selfemployment, 21 percent opted for both employment and part-time business, 15 percent were involved in postgraduate studies, 7.6 percent preferred to go to postgraduate and part-time business studies. A large proportion of respondents reported 47.2 percent of moderate abilities, while the benefits of entrepreneurship education are significantly high. The study results indicate that entrepreneurship education has a positive effect on the career plans of students in tertiary education. 
Moschandreas (2000) claimed in his study that an entrepreneur is one who helps the economic process to move the economy from a sub-optimal position to a position on the curve of the possibility of development. From this viewpoint, it is assumed that an entrepreneur assumes the role of resource manager who has the ability to distribute resources effectively to others to stimulate maximum efficiency and growth. Many who hold the Schumpeterian view, on the other hand, assume that entrepreneurs are innovators. According to this view, by adopting ideas in the form of new information, finding new tools, creating new goods, identifying new markets, entrepreneurs play that role. This mechanism contributes to an imbalance in the stable economy. This disparity provides more opportunities for entrepreneurship and development in the economy.

In Turkey, scholars such as Turker and Selcuk (2009) examined the variables affecting the entrepreneurial intent of university students in the region. A study of 300 university students was empirically evaluated using an entrepreneurial support model that they proposed. The results showed that educational and structural support factors among students influence entrepreneurial intent. In his paper presented at the 2015 NES meeting, Njerfortianalyzed NDE's entrepreneurship growth program and its capacity to build jobs. The survey was carried out in six geographical zones and, from each region, two states were chosen. The frame sample consisted of ESDP recipients and NDP trainees. The paper found that most of the participants were graduates and the high level of unemployment reported in the country was confirmed.

Braunerhjelm, (2010) shed light on recent advances in our understanding of the forces behind information development, its distribution and commercialization through innovation, and the role of the entrepreneur in the process of growth. This survey ends with the policy consequences of recent research findings. The design of regulations affecting information development, ownership, entry 
barriers, labour mobility and financial markets is especially relevant in terms of policy implications All of them have consequences for the successful dissemination of information through feedback. Incentives that induce mechanisms to turn information into social and useful needs must match the production of knowledge.

A positive relationship between entrepreneurship and growth at country level is found in Braunerhjelm; Acs; Audretsch; Braunerhjelm and Carlsson (2009), analyzing 20 OECD countries for the period 1981-2002. The influence in the 1990s is considerably greater than in the 1980s, although in the latter period the relevance of $\mathrm{R} \& \mathrm{D}$ seems to decrease. Salgado-Banda (2005) is implementing an innovative entrepreneurship measure based on quality-adjusted patent data for 22 OECD countries, which has been reported to have a positive impact on development, without any such impact on selfemployment.

Acs and Armington (2002) explored the issue of what is the relative contribution of new companies to new employment? They found that, as previously accepted, new companies play an important role in the economy.The economic history of the United States of America reveals that new establishments accounted for a large proportion of job growth in the first half of the 1990s relative to existing establishments. In addition to the industrial sector, which tends to be an exception, scholars such as Van-Stel and Suddle (2008) assume that new companies are more important than the stock of companies. These results are consistent with previous manufacturing studies.

Audretsch and Thurik (2002) conducted two independent empirical studies in a report for the OECD to identify the effect on growth of changes in entrepreneurship. Each uses a different entrepreneurship metric, country sample, and specification. This gives a sense of robustness through various entrepreneurship steps, data sets, time periods and requirements. The first study measures 
entrepreneurship in terms of the relative proportion of economic activity which small firms account for. For a panel of 18 OECD countries spanning five years, it ties improvements in entrepreneurship to growth rates to test the hypothesis that higher entrepreneurship rates lead to higher subsequent growth rates. A measure of self-employment as an indicator of entrepreneurship is used in the second study and ties shifts in entrepreneurship to country-level unemployment between 1974 and 1998.Over different time spans, the numerous samples, including OECD nations, obtain reliable results-increases in entrepreneurial activity tend to lead to higher subsequent growth rates and a reduction in unemployment.

A recent study by Sutter (2009) on US data attributes 90 percent of regional growth variance (total productivity factor) to the regional stock of expertise and the creation of new regional companies. However, it is believed that entrepreneurship has an impact on growth that is five times greater than awareness. Therefore, the empirical evidence indicates that awareness is significant for steady-state economic growth at the same time as its commercial adoption by new companies has a significantly greater effect.

\section{Materials and Method}

For this analysis, primary data samples were used. The sample size consists of members of the corps who have been posted to Delta State. Questionnaires about the entrepreneurial characteristics of literature were created for the analysis. For the 2016/2018 service year, the questionnaire was administered to National Youth Service Corps (NYSC) members posted to Delta State. Out of which 10 were found to be void for review, 130 questionnaires were administered.Although the sample used might not be so large, it is fairly representative of the research population. The research included a number of individual-specific features learned during training, such as expected skills. The NYSC camp workers, as well as those of the 
institutions under review, were also interviewed. In addition to the NYSC camp at Issele-Uku, the institutions covered in this study include: Federal College of Education, Asaba; Delta State Polytechnic, Ogwashi-Uku; Agbor and Delta State University College of Education, Abraka. The four samples were chosen using a random number table from the 12 tertiary institutions in the state.The reason for the sample size is based on time and financial considerations.

\section{Methodology}

The Chi-Square statistic is most commonly used to evaluate Tests of Independence when using a cross tabulation (also known as a bivariate table). Cross tabulation presents the distributions of two categorical variables simultaneously, with the intersections of the categories of the variables appearing in the cells of the table. The Test of Independence assesses whether an association exists between the two variables by comparing the observed pattern of responses in the cells to the pattern that would be expected if the variables were truly independent of each other.Calculating the Chi-Square statistic and comparing it against a critical value from the Chi-Square distribution allows the researcher to assess whether the observed cell counts are significantly different from the expected cell counts. The calculation of the Chi-Square statistic is quite straight-forward and intuitive:

$$
x^{2}=\sum \frac{\left(f_{0}-f_{e}\right)^{2}}{f_{0}}
$$

Where

$f_{\mathrm{o}}=$ the observed frequency and

$f_{\mathrm{e}}=$ the expected frequency, if NO relationship existed between the variables 
As depicted in the formula, the Chi-Square statistic is based on the difference between what is actually observed in the data and what would be expected if there was truly no relationship between the variables.

Table 1: Entrepreneurial and skill AcquisitionEducation and Growth

\begin{tabular}{|c|c|c|c|c|c|c|}
\hline \multirow[b]{2}{*}{$\begin{array}{l}\text { Qualific } \\
\text { ations }\end{array}$} & & \multicolumn{4}{|c|}{$\begin{array}{l}\text { Did Entrepreneurial Skill Acquisition } \\
\text { Education Enhance your job creation } \\
\text { ability for Self Employment? }\end{array}$} & \multirow[b]{2}{*}{ Total } \\
\hline & & $\begin{array}{l}\text { Strongly } \\
\text { agreed }\end{array}$ & Agreed & Disagreed & SD & \\
\hline $\begin{array}{l}\text { First } \\
\text { Degree }\end{array}$ & $\begin{array}{l}\text { Observed } \\
\text { Count } \\
\text { Expected } \\
\text { Count }\end{array}$ & $\begin{array}{l}23 \\
24.7\end{array}$ & $\begin{array}{l}19 \\
19.07\end{array}$ & $\begin{array}{l}6 \\
5.63\end{array}$ & $\begin{array}{l}4 \\
2.6\end{array}$ & 52 \\
\hline HND & $\begin{array}{l}\text { Count } \\
\text { Expected } \\
\text { Count }\end{array}$ & $\begin{array}{l}20 \\
14.25\end{array}$ & $\begin{array}{l}7 \\
11\end{array}$ & $\begin{array}{l}2 \\
3.25\end{array}$ & $\begin{array}{l}1 \\
1.5\end{array}$ & 30 \\
\hline $\mathrm{NCE}$ & $\begin{array}{l}\text { Count } \\
\text { Expected } \\
\text { Count }\end{array}$ & $\begin{array}{l}8 \\
12.35\end{array}$ & $\begin{array}{l}15 \\
9.53\end{array}$ & $\begin{array}{l}3 \\
2.82\end{array}$ & $\begin{array}{l}0 \\
1.3\end{array}$ & 26 \\
\hline $\begin{array}{l}\text { Diplom } \\
\text { a }\end{array}$ & $\begin{array}{l}\text { Count } \\
\text { Expected } \\
\text { Count }\end{array}$ & $\begin{array}{l}6 \\
5.7\end{array}$ & $\begin{array}{l}3 \\
4.4\end{array}$ & $\begin{array}{l}2 \\
1.3\end{array}$ & $\begin{array}{l}1 \\
0.6\end{array}$ & 12 \\
\hline & Value & & & & & \\
\hline $\begin{array}{l}\text { Pearson Chi- } \\
\text { Square } \\
\text { Likelihood } \\
\text { Ratio }\end{array}$ & 19.55 & s & & & & \\
\hline
\end{tabular}

Source: author's computation from respondents. 
Table 1 above presents the chi square $\left(\mathrm{x}^{2}\right)$ results on the extent to which entrepreneurship and skill acquisition ability to create job and generate employment, is influenced by the educational background of the school graduates. The Pearson chi square and likelihood ratio values of 19.55 and 22.42 are significant at the 5\% level of probability value. This implies that the entrepreneur and skill acquisition education background of the respondents have a strong impact in influencing entrepreneurship development and the ability for self-employment and job creation. This result conforms to the conclusions of Bechard and Toulouse, (1998) who found that higher institutions graduates of polytechnics and those from Universities faculties of engineering had a higher and significant probability of becoming self-employed compared to graduates of faculty of business and management sciences. Education as an instrument of knowledge diffusion is an aspect of a person's human capital that may be valuable in the discovery and exploitation of opportunities. It (education) increases a person's stock of information and skills, including those needed to recognize and pursue an entrepreneurial opportunity successfully.

\section{Summary and Recommendation}

This paper investigated the relationship between entrepreneurship education programme and jobs creation ability of tertiary institutions graduates. The Study found that most of those who took courses on entrepreneurship education indicated interest in establishing personal businesses, while twenty-two per cent of those interviewed preferred to work in private agencies and the remaining forty-six per cent prefer to work with the government. Entrepreneurship is one of the channels through which skill acquisition and innovative knowledge takes place, hence, we recommend that a good entrepreneurial curriculum should be adopted in all tertiary institutions of Nigeria. This, we believe, may lead to sustained economic progress through increased productivity. 


\section{Sunday Okubor Ijieh, PhD}

Department of Economics

College of Education, Agbor

Delta State

\section{References}

Acs, Z. and Armington, C., (2006), Entrepreneurship, Geography and Economic Growth, Cambridge University Press, New York.

Acs, Z. and Audretsch, D. (eds.), 2003, Handbook of Entrepreneurship Research: AnInterdisciplinary Survey and Introduction, Kluwer Academic Publishers, Boston, Dordrecht and London.

Acs, Z. and Szerb, L., (2009), 'The Global Entrepreneurship Index', Foundations and Trends inEntrepreneurship, 5.

Audretsch, D. and Keilbach, M. (2005). Entrepreneurship capital and regional growth. TheAnnals of Regional Science, 39(3).

Audretsch, D. and Thurik, R., (2002), 'Linking Entrepreneurship to Growth', OECD STIWorking Paper, 2081/2, OECD, Paris.

Audretsch, D., Keilbach, M. and Lehmann, E., (2006), Entrepreneurship and Economic Growth, Oxford University Press, New York.

Acs, Z. and Armington, C., (2006), Entrepreneurship, Geography and Economic Growth,Cambridge University Press, New York.

Braunerhjelm, P. (2010) Entrepreneurship, Innovation and Economic Growth - past experience,current knowledge and policy implications.CESISElectronic Working Paper Series.

Paper No. 224

Braunerhjelm, P., (2008), "Entrepreneurship, Knowledge and Growth", Foundations and Trendsin Entrepreneurship, 4.

Braunerhjelm, P. and Borgman, B., (2004), 'Geographical Concentration, Entrepreneurship andRegional Growth: 
Evidence from Regional Data in Sweden, 1975-99', Regional Studies, 38.

Braunerhjelm, P., Acs, Z., Audretsch, D., Braunerhjelm, P. and Carlsson, B., (2009), 'Then Missing Link. Knowledge Diffusion and Entrepreneurship in Endogenous Growth', Small Business Economics, 34.

Caves, R., (1998), 'Industrial Organization and New Findings on the Turnover and Mobility of Firms', Journal of Economic Literature, 36.

Ekpoh, U.I. and Edet, A.O. (2011): Entrepreneurship Education and Career Intention oftertiary Education Students in Akwalbom and Cross Rivers States, Nigeria, International Education Studies, vol. 4, No. 1

Moschandreas, M. (2000). Business Economics, Second edition, Thomas Learning BusinessPress

Romer, P., (1986), 'Increasing Returns and Long Run Growth', Journal of Political Economy,94, 1002-1037.

Schumpeter, J., (1942), Capitalism, Socialism and Democracy, Harper and Row, New York. van Stel, A. and Storey, D., (2004), 'The Link Beteen Firm Birth and Job Creation: IsThere an Upas Tree Effect?', Regional Studies, 38.

Schoof, U. (2006). Stimulating Youth Entrepreneurship: Barriers and Incentives to Enterprise start-ups by Young People, ILO Seed Working Paper No. 76. van Stel, A. and Suddle, K., (2008), 'The Impact of New Firm Formation on RegionalDevelopment in the Netherlands', Small Business Economics, 30. 